\title{
POWER PRODUCTION AND CONSUMPTION
}

$\mathrm{T}$ HE Fifth World Power Conference took place in Vienna during June last, the only other meeting since the Second World War having been held in London in 1950. There were thus the results of six years of progress to consider. Some 275 papers from thirty-five nations, including the U.S.S.R., were presented, covering a very wide field divided for convenience into five divisions, each division being sub-divided into several sections. The classification was as follows: Division I: The Present Status and Development of Power Production and Utilization in National Economy (58 papers); Division II : Preparation and Conversion of Fuels (55 papers); Division III : Utilization of Primary Sources of Energy (137 papers) ; Division IV : Purification of Waste Water and Exhaust Gas (8 papers); Division V: International Co-operation in the Production and Use of Energy (11 papers). It is only possible in this review to comment briefly on the trends noticeable in the general reports covering the contents of the several papers presented in each section.

The picture presented of the relation between power consumed and the available resources of fossil fuels is on one hand encouraging, in that there has been an increase in the power consumed in the whole world, and on the other hand perturbing, in that the proved reserves of all fossil fuels show little signs of supplying economically the required energy for any considerable period of time. Estimates of fuel reserves differ, and some countries are much better off than others; but it appears as a virtual certainty that the exploitation of nuclear resources and the vast but inconvenient, and at present uneconomic, potentials of water, wind and sun will be rapidly forced upon industrial nations.

Coal production is a major problem in most countries, except in the United States, where the known reserves are 10,000 tons per capita as against, for example, 0.43 in Austria. In India and in Britain coal production has actually declined. Perhaps the most important general observation of the world coal situation which may be made is that it is the difficulty of obtaining the right type of coal for particular applications which is of greater moment than the actual quantity produced. For example, the rapid increase in steel production together with the decrease in availability of suitable coking coals are causing considerable research to adapt less suitable coal to coking methods. In 1955 pulverized coal consumption was 19 million tons in Britain as opposed to 8 million tons in 1950 . In twenty years in the Federal German Republic, refuse in hard coal mines rose to 24 per cent-double its previous figure. Methods of handling, washing, cleaning and processing coal are therefore being improved as its value appreciates, and quality falls.

The use of petroleum is increasing at a greater rate than that of coal and now accounts for about one-third of the total world energy demand. An interesting point is that while the United States is still incomparably the world's largest consumer of petroleum products ( 53 per cent), the proved reserves of Saudi Arabia and Kuwait are together more than double those of North America.

The trend in the utilization of raw oil varies slightly in different countries. In Great Britain since 1950 there has been a decline in the pro- portion of oil used for petrol, a small increase in that used for diesel fuel, and a larger increase in the proportion of distillates and residuals for furnace oil ; a similar trend occurred in the German Federal Republic. This was in contrast with the United States, where the percentage demand for residuals rose only slowly, while the demand for petroleum fuels and medium distillates increased briskly due to use for jet aircraft, diesel locomotives and motor fuels. There appears to be a relative increase in the use of diesel engines in all the major industrial countries, excluding Japan, where curiously there is a pronounced decrease.

The most striking development of the petroleum industry is the advance in the refining technique and the improved method of production of various grades of end-products. In particular, catalytic cracking and re-forming plants have largely replaced thermal plants. Demand for and production of high-octane motor petrols have both increased, the premium grade octane number now being greater than 90 , compared with 80 in 1940 . The diesel fuel situation shows less improvement, as diesel running costs are kept low by engines prepared to digest a wide fuel cut. However, desulphurization processes are likely to be improved.

The gas industry is often regarded by the general public as an obsolescent concern. In fact, this is far from the truth. The extension in the use of natural gas in those countries blessed with this resource is quite remarkable. In the United States, some 25 per cent of the total power supplied comes from combustion of natural gas. In Britain, experiments have been carried out to obtain gas from coal of high ash content directly out of the seam. It is perhaps significant that it has been found necessary to devote a complete section to the discussion of long-distanee transmission of gas. Natural gas reserves are being exploited, particularly in the United States, Italy and France, and a long-distance line of some 1,100 miles has been completed in the Argentine. With such developments it may soon be feasible to transport natural gas from the Middle East oil-fields to the extreme west of Europe. It is already possible to transport cooled liquefied ethylene in railway trucks, and some authorities expect that liquid methane will be transported by tanker from the Middle East. An interesting problem, to quote the general report, will be "to find some use for this large quantity of cold which will be liberated when vaporizing the liquid methane at the place of delivery".

In countries with no natural gas supplies, the use of gas is also increasing. This is due to gas production as a by-product from the coke and oilrefining industries, and the realization that the gases from blast furnaces may be integrated into a gas grid system. Several countries are considering use for the methane obtained from mine ventilation; possibly this may be burnt in a gas turbine if the mixture is weak, or, as in the Saar, supplied to cracking plants, before feeding to the grid. The economic use of sewage gas is discussed only in a paper from Britain, where sludge gas is used to drive dual-fuel engines or gas turbines.

The fact that the percentage produced by water of the total electrical power consumed has decreased in both Europe and America, should not conceal the 
great advances made in the quantity of power produced hydraulically, or the improvements in that science. Most countries have made extensive investigation of their hydraulic resources. Improvements in long-distance transmission of electricity have encouraged developments of hydraulic projects distant from industrial centres. The general tendency is for schemes to be planned as multi-purpose works where flood control, irrigation or navigation benefit, in addition to the production of electric power. Data of water power available, compared with that utilized, show that while Europe, particularly in Italy, Sweden and Switzerland, is near the possible economic limit of development, less water power is produced in Africa than in any other continent, though its potential is by far the largest. The potential of South America is considered to be less than that of Europe. Experimental techniques, such as the use of models and photo-elastic analysis of dam stresses, are now more in evidence in the design stage, while during construction improvements have been rather in details and in constructional technique than in fundamentals. One feature is the popularity of underground power houses. The huge Kemano project in Canada envisages a chamber $1,146 \mathrm{ft} . \times$ $82 \mathrm{ft}$. $\times 131 \mathrm{ft}$. to house $2 \cdot 4$ million h.p. The capacity of the units in the larger projects has been raised; for example, Kaplan turbines of $111,000 \mathrm{~h} . \mathrm{p}$. at MeNary, U.S.A., Francis turbines of 165,000 h.p. at Grand Coulee, U.S.A., and Pelton wheels of 150,000 h.p. at Kemano and Cimego, Italy. The efficiencies of machines have also risen, average figures quoted being 93 per cent for Kaplan turbines, 92 per cent for Francis turbines, 91 per cent for Pelton wheels. The maximum single-generator capacity is $160 \mathrm{MW}$. (Stornorrfors, Norway), while plants with an overall output of $100 \mathrm{MW}$. are now considered of medium size. Kaplan turbines handle heads up to $776 \mathrm{ft.}$, Francis turbines up to $1,476 \mathrm{ft}$. and Pelton wheels up to $5,740 \mathrm{ft}$.

Apart from the orthodox hydraulic schemes, some progress has been made with the long discussed possibility of harnessing tides. Electricité de France intends to erect a tidal-power plant at the mouth of the Rance. Turbine and generator will be reversible, so that power may be produced both on flood and ebb tides. There are thirty-eight units, each consisting of a Kaplan turbine and alternator, the total output being $9,000 \mathrm{~kW}$. Further schemes for the Chausey and Minquiers Islands are projected.

The sections on atomic energy are not quite so large as might have been expected in view of the intense interest aroused by this subject. This is probably due to the short interval since the end of the International Congress on the Peaceful Uses of Atomic Energy held in Geneva last year. In view of the evident shortage of world coal and oil supplies, the importance of the discovery of large resources of fissile material cannot be over-emphasized. It can scarcely be expected that these resources have been determined to even a fraction of the degree of accuracy to which those of petroleum and coal are known. Nevertheless, conservative estimates suggest that the energy available, even with relatively low station efficiencies of 18 per cent, is at least an order greater than that from fossil fuel resources.

The state of reactor design would appear most satisfactory: precisely because no one type has yet been shown to have decisive advantages. Thus many variations are under construction or in use in a single country. Broadly, reactors are of two types, the heterogeneous reactor, in which rods of the fuel element are distributed throughout the moderator and a coolant is passed through the reactor core, and the homogeneous reactor where the fuel and moderator are intimately mixed, for example, as a solution, the solution itself being circulated through a heat exchanger. Within this broad classification many important differences of design may arise. It is, for example, by no means clear what are the most suitable combinations of moderator and coolant, or what is the better choice between thermal and fast reactors. In Britain, the Calder Hall Station uses natural uranium with a graphite moderator and compressed carbon dioxide as a coolant. This type of reactor suggests a relatively low cost per $\mathrm{kW}$. output and a high safety factor, an over-riding consideration in a densely populated country. Graphite reactors with water and liquid sodium cooling are in use in the U.S.S.R. and the United States. Water may be used as both moderator and as coolant and, if allowed to boil, may be fed directly to a turbine. In the United States, a boiling-water 2-MW. plant is in operation, a 5-MW. plant under construction and a 180-MW. plant planned. Fast reactors are also undergoing development; but no report on their progress was submitted to the Vienna Conference.

After further development, homogeneous reactors are likely to be as popular as the heterogeneous reactors; they have certain technical advantages, but to cope with the high pressures at which they must operate to ensure good thermodynamic efficiency and to provide them with heavy water solvent or enriched uranium, the capital cost is high. Both the United States and the Netherlands are carrying out such development.

The main problem in the application of the reactor to power production is the low temperatures which can be withstood by the constructional materials of the reactors while still preserving low neutron absorption and hence fuel economy. The problem is largely a metallurgical one, and progress is being made. The attention paid to building nuclear power stations varies directly with the degree of a nation's industrialization, and with the scarcity of its available reserves of fossil fuels. It is thus not surprising to find Britain in the forefront of commercial development with a proposed programme of twelve plants of a maximum possible output of 2,000 MW. by 1957 and that by 1975 it is planned that equal amounts of electricity shall be yielded by coal and atomic plants. International opinion differs as to the desirability of producing atomic power. The correct solution must depend upon the local economics. The situation in Britain, where coal production is on the decline, must involve an entirely different solution from that in the United States, where in some cases it is only economic to exploit 55 per cent of a coal seam, so plentiful are reserves.

Whatever the form of thermal energy producer most economic in the future, the energy produced will be largely utilized as electrical energy. In Europe (not including the U.S.S.R.) there seems to be an annual increment of 8 per cent in the electricity consumed, which suggests that the electrical output may about double itself in a decade. The demand for electrical energy, 5 per cent of the total energy demand in Europe, is rising at almost twice the rate of the total energy demand. Excluding the U.S.S.R., China and Eastern Europe, the 1954 index was 137 units compared with 100 in 1948. 
There is, therefore, more than ever a widespread interest in thermal power stations, of which the turbines and generators at least are likely to be the instruments of power conversion from nuclear reactors. With the decrease in availability of coals, it is becoming essential that power stations shall generate at the maximum efficiency and thus steam. plant design is becoming more complicated. Multiple reheat and bleed-steam preheating systems using up to nine stages are being applied, more perhaps in the United States than in Europe, to approach more closely the Carnot cycle.

A whole section was devoted to the construction and operation of steam boilers. In the search for higher efficiencies, steam generating temperatures have risen by $18^{\circ} \mathrm{F}$. per annum, the maximum value now being about $1,200^{\circ} \mathrm{F}$., a temperature at which austenitic steels must be used. Below this a gap in the range exists, the maximum temperature feasible for ferritic steels being about $1,000^{\circ} \mathrm{F}$. Operational pressures have risen to very high figures, especially when reheat is introduced; two commercial examples are 1,150 and $2,850 \mathrm{lb}$. per sq. in., while experimental plant uses up to 5,000 lb. per sq. in. Average boiler capacities have risen to between 450,000 and $900,000 \mathrm{lb}$. per $\mathrm{hr}$, with some boilers generating 2,400,000 lb. per hr. Boiler efficiencies of 90 per cent are reported and availability is nearly 100 per cent. Boiler systems are largely orthodox, of the natural circulation drum type, but forced circulation monotube boilers are used to an increasing extent, particularly on the Continent of Europe. Design of boilers is also being influenced by the necessity for burning inferior coals with their more acute flue cleaning and ash disposal problems. One new method of cleaning the convection heating surfaces on load is to pour small steel balls over the tubes, and collect them in the ash hopper, where they are removed from the ash and cleaned.

Steam boilers appear to be in their heyday, possibly at about the stage of development of the reciprocating engine in the year 1900. No doubt bigger and better boilers are yet to come; but, to quote the general report, "it seems that developments in the field of atomic energy will outdate endeavours towards a further improvement in existing methods of power generation". Steam generation by nuclear reactor heat is the problem of the immediate future. The temperatures available are unfortunately low, $500^{\circ} \mathrm{F}$. with water-cooled, possibly $750^{\circ} \mathrm{F}$. with sodium-cooled fast breeder reactors. It is suggested that compound plants where superheating is accomplished by oil firing may be evolved.

Many other aspects of power generation are treated by one or more papers. Developments in the use of solar energy-never of great concern in the temperato zone-have progressed to some extent; but direct use of the sun's heat is still inconvenient and usually uneconomic. Even in India the preference of an oriental population for preparing their meals in the evening has reduced the sale of solar cookers. Heat pumps and fuel cells, the latter of great academic interest, are discussed in British papers, while complete sections are devoted to statistical compilation of data, purification of industrial effluents, and the technical and economic aspects of international co-operation.

The tremendous field covered at the Conference must be apparent from the number of papers presented by thirty-five countries. It is inevitable that somewhere the field must be bounded and that all the field may not be covered in the detail some would wish. For example, the application of power to transport, the developments of gas turbines and diesel and free-piston engines are only briefly considered. It is also disappointing that more attention was not given to the reminder of the president, Sir Harold Hartley, who said in his address: "Food is the most urgent need of the world to-day and I would ask you if we are devoting enough thought to the place of power in agriculture as compared with the emphasis we place on industry. . . .".

Generally, the tone of the Conference was optimistic, in spite of the shadow cast by falling fuel resources: the tone seems to be one of certainty that more and more power will be needed, combined with an equal certainty that a wider search for power reserves, coupled with a more effective use of known resources, and development of nuclear reactors, will provide that power. Finally, a word in praise must be said for the general reports summing up the proceedings of each section. These are admirably translated into French, German and English, and are remarkable for their concise and balanced interpretation of the mass of technical data presented. They are worthy of an international conference, which presents a remarkably clear picture of presentday practice and of the directions in which scientific research in power production is leading.

F. D. RoBINSON

\section{ANIMAL REPRODUCTION}

\section{THIRD INTERNATIONAL CONGRESS IN CAMBRIDGE}

$\mathrm{T}$ HE Third International Congress on Animal Reproduction, attended by more than five hundred representatives of no fewer than fifty different countries, was held in Cambridge during June 25-30. The proceedings were conducted in three sections, devoted to physiology, pathology and artificial insemination, respectively. About one hundred and fifty papers were presented, many of which were concerned with the practical aspects of animal breeding, clinical problems, and technical advances in the methods of semen storage and artificial insemination. A noteworthy feature of the Congress, however, was the relatively high proportion of papers of more general scientific interest, dealing with the physiology of mammalian gametes and the early stages of embryonic development. The growing impact of two fundamental sciences in particular, namely, biophysics and biochemistry, on research in the field of animal reproduction, was specially evident from the nature of the Congress exhibits and 